\title{
Depigmentory Effects of Keishibukuryogankayokuinin in Human Epidermal Melanocytes
}

\author{
Kaho Akimoto1 $^{1}$ (), Takuji Yamaguchi², Yuna Naraoka ${ }^{3}$, Ailing Hu², Hiroyuki Kobayashi1 \\ ${ }^{1}$ Department of Hospital Administration, Graduate School of Medicine, Juntendo University, Tokyo, Japan \\ ${ }^{2}$ Center for Advanced Kampo Medicine and Clinical Research, Graduate School of Medicine, Juntendo University, Tokyo, Japan \\ ${ }^{3}$ Japanese Center for Research on Women in Sport, Juntendo University, Tokyo, Japan \\ Email: k-akimoto@juntendo.ac.jp
}

How to cite this paper: Akimoto, K., Yamaguchi, T., Naraoka, Y., Hu, A.L. and Kobayashi, H. (2019) Depigmentory Effects of Keishibukuryogankayokuinin in Human Epidermal Melanocytes. Health, 11, 869-879. https://doi.org/10.4236/health.2019.117070

Received: May 30, 2019

Accepted: July 8, 2019

Published: July 11, 2019

Copyright ( 2019 by author(s) and Scientific Research Publishing Inc. This work is licensed under the Creative Commons Attribution International License (CC BY 4.0).

http://creativecommons.org/licenses/by/4.0/ (c) (i) Open Access

\begin{abstract}
Keishibukuryogankayokuinin (KBY) is a traditional Japanese herbal medicine widely used to treat skin pigmentation. The scientific basis for its use is, however, unclear, and studies evaluating its mechanism and effectiveness are sparse. In this study, we compared the tyrosinase inhibitory effects of KBY and Keishibukuryogan (KB, which has the same composition of KBY, except Coix Seed [CS]) and CS under exposure to UV radiation as well as under non-exposure conditions. Neonatal human epidermal melanocytes obtained from a darkly pigmented donor were used. These cells were cultured in a final concentration of $500 \mu \mathrm{g} / \mathrm{ml}$ or $1000 \mu \mathrm{g} / \mathrm{ml}$, to which KBY, KB, and CS were added. After incubation for $72 \mathrm{~h}$, cells were stained with Fontana-Masson stain and counted. Tyrosinase activity was measured by its dopa oxidase activity, and tyrosinase expression was estimated using real-time PCR. For UV radiation, cells were exposed to UVB radiation for $90 \mathrm{~s}$ per day for 3 days. Under non-exposure conditions, tyrosinase activity significantly increased with both KBY and KB but significantly decreased with CS, regardless of the concentration. In addition, tyrosinase expression significantly decreased but only with KBY at both concentrations. Under UV radiation exposure, tyrosinase activity significantly increased with $\mathrm{KBY}$ and $\mathrm{KB}$ at both concentrations while tyrosinase expression significantly decreased with $\mathrm{KBY}$ and $\mathrm{KB}$; a significant increase was, however, observed with CS at both concentrations. These results suggest that taking KBY after sunburn is effective against skin pigmentation, and the combination of $\mathrm{KB}$ and $\mathrm{CS}$ is useful for skin depigmentation.
\end{abstract}

\section{Keywords}

Keishibukuryogankayokuinin, Coix Seed, UVB, Tyrosinase, Melanocytes 


\section{Introduction}

Recently, the aging population in Japan has become a growing social problem [1] [2]. As life expectancy increases, it is important that we not only live longer, but also enjoy a high quality of life. Aging and the quest to "maintain a youthful appearance" have therefore attracted a heightened interest from not only the point of view of science, but also from society; the latter has been occurring throughout human history [3]. Among others, senescence of the skin affects appearance. In fact, spots and wrinkles due to photoaging, are major factors that indicate aging [4]. Rexbye et al. reported that a youthful facial appearance correlates with prolonged survival and that several environmental factors are associated with facial aging [5]. Furthermore, it has been known that skin conditions, such as dermatitis or skin rash, impact our psychological and physical functions in daily life [6] [7]. Lifestyles that prevent facial skin aging therefore lead to overall improvement in one's health [8] [9]. Although skin aging is associated with one's appearance, preventing and treating aging skin improve one's mental health and the health of the body.

The color of the skin surface is not uniform. If the skin's internal pigment such as melanin and hemoglobin is excessively secreted, it is perceived as spots, color irregularity or dullness, and spots especially are pigmentation caused by excessive secretion of melanin in the epidermis [10]. Although the mechanism of pigmentation is not completely clear, tyrosinase has been identified as a rate-controlling enzyme [11] [12]. In fact, many cosmetics and quasi-pharmaceutical products are sold as whitening agents for spots which inhibit the activity or reduce the expression of tyrosinase [11]. It is also noteworthy that contact dermatitis and various adverse effects have been reported [13] [14]. Pigmentation inhibitors that are confirmed to be efficacious by evidence-based medicine are expected [12].

Keishibukuryogankayokuinin (KBY), a traditional Japanese herbal medicine that is widely used in clinical settings, is recommended to remove spots from the skin [15]. Traditional Japanese herbal medicines have been established owing to over thousands of years of study on their use as therapeutics. These studies have led to the confirmation of beneficial, herbal combinations without harmful effects [16]; however, currently, there is a lack of scientific evidence to support their use, and only very little is known about the efficacy and mechanism of KBY. Therefore, in this study, we investigated the potential mechanism of KBY, as well as Keisibukuryogan (KB, which has the same composition of KBY, except Coix Seed [CS]) and CS, based on tyrosinase.

\section{Materials and Methods}

\subsection{Traditional Japanese Herbal Medicine}

The dried extract powder of KBY and KB used in the study were supplied by Tsumura \& Co. (Tokyo, Japan). KBY is composed of six dried medicinal herbs-Coix Seed, Cinnamon Bark, Peony Root, Peach Kernel, Poria Sclerotium, 
and Moutan Bark. KB is composed of five dried medicinal herbs-Cinnamon Bark, Peony Root, Peach Kernel, Poria Sclerotium, and Moutan Bark. CS was purchased from Tsumura \& Co. and extracted with boiling water for $1 \mathrm{~h}$. The extracts were evaporated and dried.

\subsection{Cell Culture and UV Radiation}

We obtained neonatal human epidermal melanocytes from a darkly pigmented donor (HEMn-DP; Gibco, USA) and cultured these cells in Medium 254 (Gibco) containing Cascade Biologics HMGS 100X (Gibco). The mixture was incubated at $37^{\circ} \mathrm{C}$ and $5 \% \mathrm{CO}_{2}$. After culture, $\mathrm{KBY}, \mathrm{KB}$, and $\mathrm{CS}$ were added in a final concentration of $500 \mu \mathrm{g} / \mathrm{ml}$ or $1000 \mu \mathrm{g} / \mathrm{ml}$. After incubation for $72 \mathrm{~h}$, the cells were used for the experiments. For UV radiation, cells were exposed to UVB radiation using a Handheld UV Lamp (Analytik Jena US LLC, USA) for 90 s per day for 3 days.

\subsection{Cell Staining}

We captured images after staining the cells with the Fontana-Masson Stain Kit (ScyTek Laboratories, Inc., USA) following the manufacturer's protocols.

\subsection{Cell Viability}

After cell culture, cell viability was measured using Cell Counting Kit-8 (Dojindo Molecular Technologies, Inc., Japan) following the manufacturer's protocols. After incubation at $37^{\circ} \mathrm{C}$ for $1 \mathrm{~h}$, absorbance was measured at $405 \mathrm{~nm}$.

\subsection{Tyrosinase Activity}

Tyrosinase activity was measured via its dopa oxidase activity with reference to the method described by Fujiwara et al. [17]. After cell culture, cells were recovered using Trypsin/EDTA (Cell Applications, Inc., USA). The supernatant was removed, and Triton ${ }^{\mathrm{TM}} \mathrm{X}-100$ (Sigma-Aldrich, USA) was added to elute intracellular substances from the melanocytes. N,N-Dimethylformamide (Sigma-Aldrich) adjusted to 4\% with PBS pH 7.4 (Gibco) and 3,4-Dihydroxy-L-phenylalanine (Sigma-Aldrich) adjusted to $5 \mathrm{mM}$ with PBS were added to the melanocyte solution. Absorbance at 0 min was measured at $405 \mathrm{~nm}$, followed by incubation at $37^{\circ} \mathrm{C}$ for $30 \mathrm{~min}$. Absorbance was again measured at 30 $\min$.

\subsection{Tyrosinase Expression}

Tyrosinase expression was estimated with real-time PCR by referring to the method described by Masaki [11]. Cells were collected using RNeasy Mini kit (QIAGEN, Netherlands), and total RNA was extracted. Reverse transcription was carried out using $100 \mathrm{ng}$ of RNA with the High Capacity cDNA Reverse Transcription Kit (Applied Biosystems, USA) to synthesize cDNA. The reaction conditions were: $25^{\circ} \mathrm{C}$ for $10 \mathrm{~min}$, and $37^{\circ} \mathrm{C}$ for $120 \mathrm{~min}$. qPCR was performed 
using PikoReal 96 (Thermo Fisher Scientific, USA). We used TaqMan ${ }^{\circledR}$ Universal PCR Master Mix, No AmpErase ${ }^{\oplus}$ UNG (Applied Biosystems) and TaqMan ${ }^{\circledR}$ Gene Expression Assays as probes. We also used tyrosinase (TYR: Hs00165976_mL; Applied Biosystems) as the target gene and GAPDH (Hs99999905_mL; Applied Biosystems) as the standard internal gene. The reaction solution was $20 \mu \mathrm{L}$ and reaction conditions were: $95^{\circ} \mathrm{C}$ for $10 \mathrm{~min}, 95^{\circ} \mathrm{C}$ for $15 \mathrm{~s}$, and $60^{\circ} \mathrm{C}$ for $1 \mathrm{~min}$ $\times 50$.

\subsection{Data Analysis}

The experimental data are expressed as mean \pm S.E. Paired t-test was used to detect any differences in each condition. A $p$ value $<0.05$ was considered statistically significant.

\section{Results}

\subsection{Cell Staining}

Figure 1 represents the results of staining for the investigation of cell viability.

\subsection{Cell Viability}

Under non-irradiated conditions with a final concentration of $1000 \mu \mathrm{g} / \mathrm{ml}$, we observed a significant decrease in cell viability with KBY (73.91 $\pm 0.76, p<$ $0.001)$ and $\mathrm{KB}(56.90 \pm 0.73, p<0.001)$ (Figure 2(a)). However, with $500 \mu \mathrm{g} / \mathrm{ml}$ as the final concentration, cell viability was observed to significantly increase with KBY $(110.92 \pm 0.71, p=0.032)$ (Figure 2(a)). Under UV exposure with a final concentration of $1000 \mu \mathrm{g} / \mathrm{ml}$, we observed a significant increase in cell viability with KBY $(120.62 \pm 1.48, p=0.011)$ and CS $(134.08 \pm 2.84, p=0.002)$ (Figure 2(b)). Similarly, with $500 \mu \mathrm{g} / \mathrm{ml}$ as the final concentration, cell viability significantly increased with KBY (144.34 $\pm 1.13, p<0.001), \mathrm{KB}(156.24 \pm 1.64, p<$ $0.001)$, and CS (137.36 $\pm 2.29, p=0.010)$ (Figure 2(b)).

\subsection{Tyrosinase Activity}

Under non-irradiated conditions, tyrosinase activity significantly increased with KBY $(500 \mu \mathrm{g} / \mathrm{ml}: 142.30 \pm 2.02 ; 1000 \mu \mathrm{g} / \mathrm{ml}: 151.18 \pm 0.97)$ and $\mathrm{KB}(500 \mu \mathrm{g} / \mathrm{ml}:$ $181.79 \pm 3.64 ; 1000 \mu \mathrm{g} / \mathrm{ml}: 188.21 \pm 1.26$ ), but significantly decreased with CS $(500 \mu \mathrm{g} / \mathrm{ml}: 80.30 \pm 0.54 ; 1000 \mu \mathrm{g} / \mathrm{ml}: 81.61 \pm 0.52)$, regardless of the concentration $(p<0.001)$ (Figure $3(\mathrm{a})$ ). In contrast, tyrosinase activity was significantly increased with $\mathrm{KBY}(500 \mu \mathrm{g} / \mathrm{ml}: 161.62 \pm 2.44 ; 1000 \mu \mathrm{g} / \mathrm{ml}: 232.57 \pm 4.71)$ and $\mathrm{KB}(500 \mu \mathrm{g} / \mathrm{ml}: 231.62 \pm 3.57 ; 1000 \mu \mathrm{g} / \mathrm{ml}: 285.49 \pm 6.87)$ at both concentrations $(p<0.001)$ when exposed to UV (Figure 3(b)). Furthermore, the rate of increase for KBY was significantly lower than KB under all conditions $(p<0.001)$.

\subsection{Tyrosinase Expression}

Under non-irradiated conditions, tyrosinase expression significantly decreased only with KBY at both concentrations $(500 \mu \mathrm{g} / \mathrm{ml}: 84.04 \pm 0.47, p<0.001 ; 1000$ 

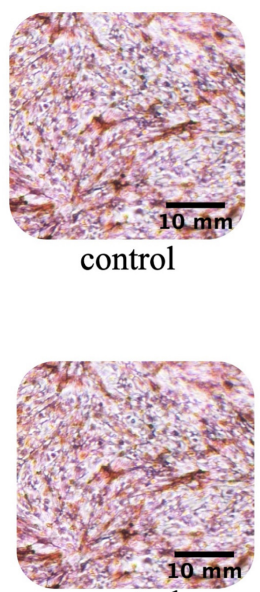

control

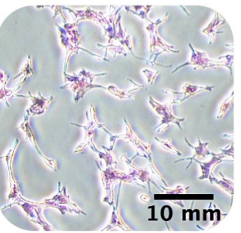

control

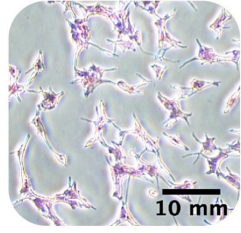

control

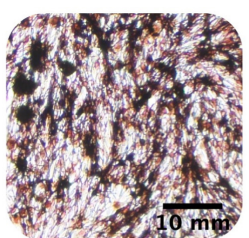

KBY

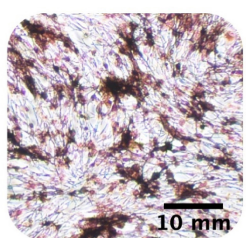

KB

(a)

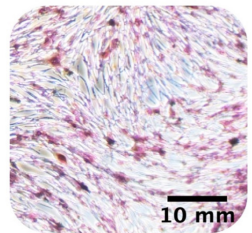

KBY

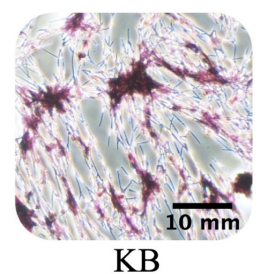

(b)

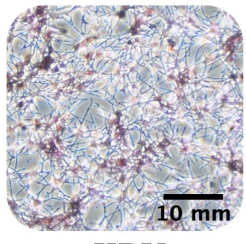

KBY

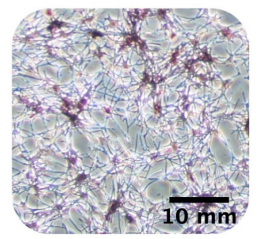

KB

(c)
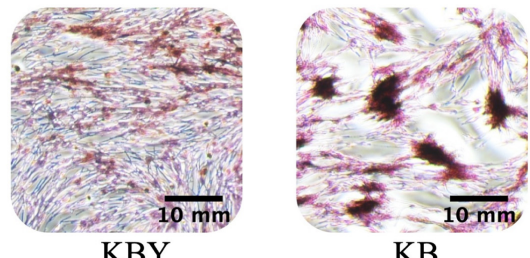

$\mathrm{KB}$

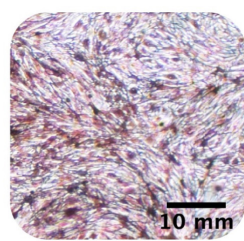

CS

(d)

Figure 1. Fontana-Masson staining of HEMn-DP with or without UV exposure. KBY, $\mathrm{KB}$, and CS were added to make a final concentration of $500 \mu \mathrm{g} / \mathrm{ml}$ or $1000 \mu \mathrm{g} / \mathrm{ml}$. (a) Under non-irradiated conditions, $500 \mu \mathrm{g} / \mathrm{ml}$, (b) Under non-irradiated conditions, 1000 $\mu \mathrm{g} / \mathrm{ml}$, (c) Under UV exposure, $500 \mu \mathrm{g} / \mathrm{ml}$, (d) Under UV exposure, $1000 \mu \mathrm{g} / \mathrm{ml}$.
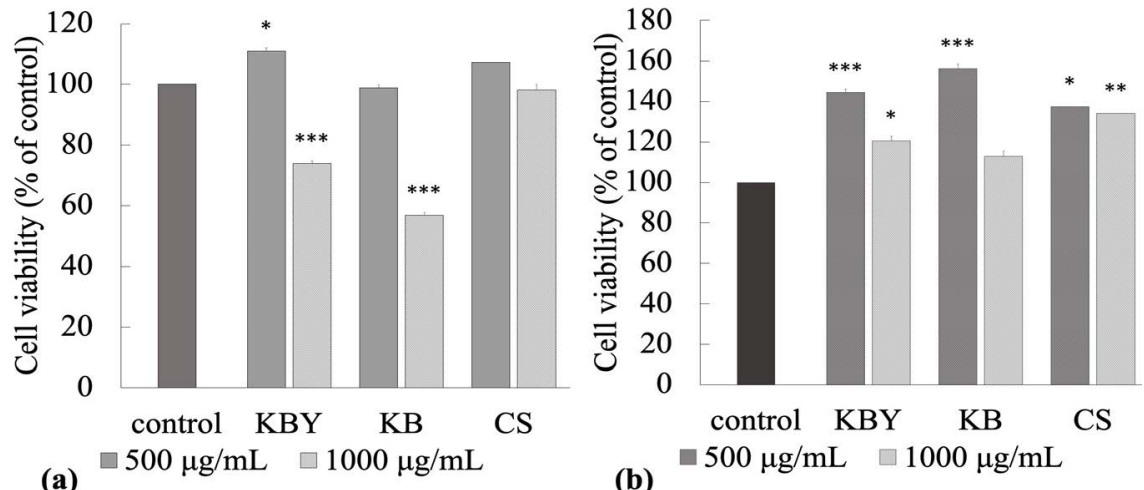

Figure 2. Effects of $\mathrm{KBY} / \mathrm{KB} / \mathrm{CS}$ on cell viability. (a) Under non-irradiated conditions, and (b) With UV exposure. Results are expressed as mean \pm S.E. ${ }^{\star} p<0.05,{ }^{* *} p<0.01$, ${ }^{* * *} p<0.001$ vs. control. 


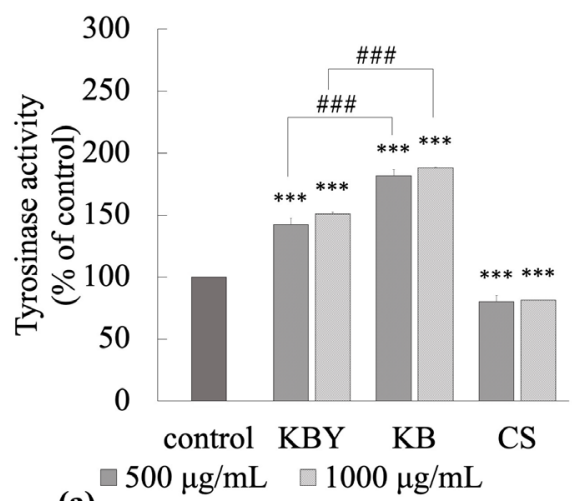

(a)

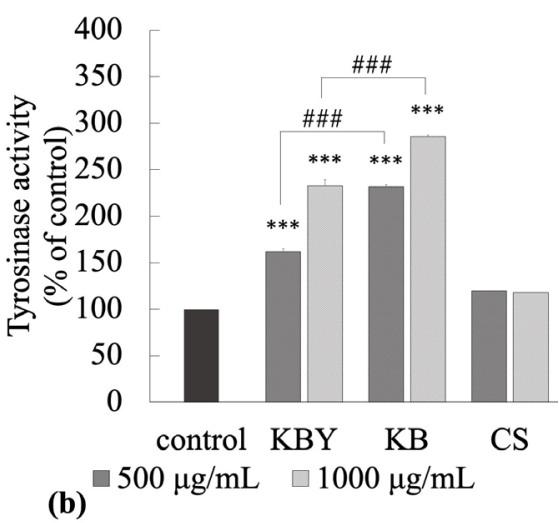

Figure 3. Effects of $\mathrm{KBY} / \mathrm{KB} / \mathrm{CS}$ on tyrosinase activity. (a) Under non-irradiated conditions, and (b) With UV exposure. Results are expressed as mean \pm S.E. ${ }^{\star * \star} p<0.001$ vs. control. ${ }^{\# \#} p<0.001$ when KBY is compared to KB.

$\mu \mathrm{g} / \mathrm{ml}: 84.41 \pm 1.43, p=0.020$ ) (Figure $4(\mathrm{a})$ ). Similarly, with UV exposure, this expression was significantly decreased with KBY $(500 \mu \mathrm{g} / \mathrm{ml}: 63.75 \pm 0.58 ; 1000$ $\mu \mathrm{g} / \mathrm{ml}: 53.44 \pm 0.53)(p<0.001)$ and $\mathrm{KB}(500 \mu \mathrm{g} / \mathrm{ml}: 65.53 \pm 0.65 ; 1000 \mu \mathrm{g} / \mathrm{ml}:$ $61.99 \pm 0.94)(p<0.001)$ (Figure $4(\mathrm{~b}))$. However, a significant increase was observed with CS at both concentrations $(500 \mu \mathrm{g} / \mathrm{ml}: 140.11 \pm 1.11 ; 1000 \mu \mathrm{g} / \mathrm{ml}$ : $122.35 \pm 0.87)(p<0.001)$ (Figure 4(b)).

\section{Discussion}

Melanin protects our skin from UV damage, but an increase in its production can cause abnormal pigmentation which can affect one's psychosocial behavior and trigger issues with appearance [18]. Many studies have been conducted to develop whitening agents and many have reported that various naturally occurring compounds inhibit the activity or expression of tyrosinase [19] [20] [21]. For example, kojic acid, hydroquinone, and arbutin are direct inhibitors of tyrosinase activity [18] [21] [22]. Although the effectiveness of hydroquinone (as an example) has been demonstrated when used as a treatment, its use has been considered problematic due to cytotoxicity to melanocytes [18] [23]. An ideal whitening agent has no side effects and gives a potent and selective skin whitening effect to pigmented areas.

$\mathrm{KBY}$, a traditional Japanese herbal medicine widely used in clinical settings, is recommended to remove spots from the skin [15]. However, these medicines presently lack scientific evidence and for KBY, there is very little known about its efficacy and mechanism. KBY is used to relieve the following symptoms: menstrual irregularity, automatic imbalance syndrome (which resembles climacteric disturbance in women), acne, spots, and roughness of the hands and feet. However, KB is not indicated for the relief of symptoms of the skin because it lacks CS, which has an effect on the skin. CS is a crude drug that is prepared by drying mature seeds, excluding the seed coat of Coixlacryma-jobi Linne var. mayuen Stapf [24]. Although its active ingredient and pharmacological effect remain unclear, it has been used to treat warts and skin-related issues [25] [26]. 


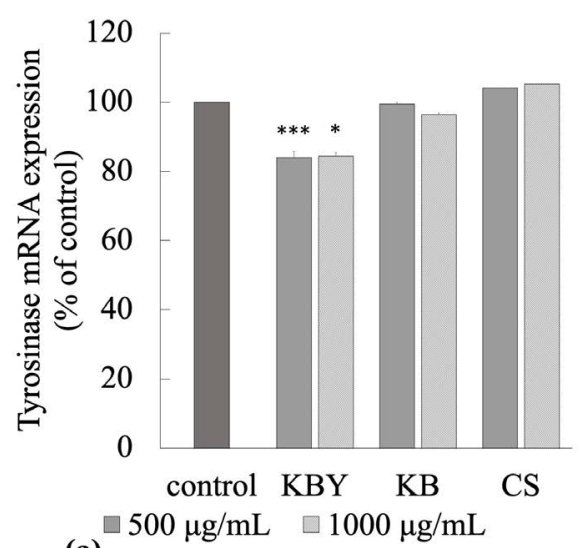

(a)

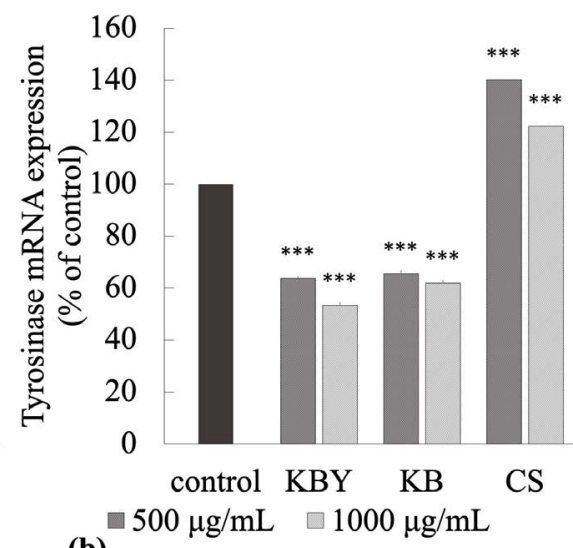

(b)

Figure 4. Effects of $\mathrm{KBY} / \mathrm{KB} / \mathrm{CS}$ on tyrosinase activity. (a) Under non-irradiated conditions, and (b) With UV exposure. Results are expressed as mean \pm S.E. ${ }^{\star} p<0.05,{ }^{\star * \star} p<$ 0.001 vs. control.

Melanocytes respond to various factors such as the surrounding environment (e.g., UV), or neighboring cells in the skin [27] [28]. In the early stage of melanogenesis, L-tyrosine or L-3,4-dihydroxyphenylalanine (L-DOPA) is converted to the corresponding o-dopaquinone by enzymatic oxidation of tyrosinase [28] [29]. This tyrosinase catalyzes two rate-limiting steps during melanogenesis: 1) hydroxylation of tyrosine to L-DOPA, and 2) oxidation of L-DOPA to dopaquinone [30]. While tyrosinase regulates the rate-limiting steps in the early stage of melanogenesis, tyrosinase related protein (TRP)-1 and TRP-2 are involved in modifying eumelanin in the later steps [21]. Furthermore, microphthalmia-associated transcription factor (MITF) is the major transcription factor in the regulation of tyrosinase, TRP-1, and TRP-2 [21] [22]. Extensive studies on the whitening effects have been performed to elucidate the activity and expression of these enzymes, specifically tyrosinase [21]. We also investigated the effect of KBY-induced melanin inhibition, especially the effect on tyrosinase activity and expression, in HEMn-DP.

We measured cell viability to exclude the possibility that the tyrosinase inhibitory effects of KBY, KB, and CS might be caused by cell growth inhibition [28]. Under non-irradiated conditions and with a final concentration of $1000 \mu \mathrm{g} / \mathrm{ml}$, a significant decrease in cell viability was observed with $\mathrm{KBY}$ and KB; however, with $500 \mu \mathrm{g} / \mathrm{ml}$ as the final concentration, a significant increase in cell viability was observed with KBY. These results and the result of Fontana-Masson staining suggest that $\mathrm{KBY}$ and $\mathrm{KB}$ might exert cytotoxicity (i.e., they may have an optimal concentration). However, as reported for other traditional Japanese herbal medicines, there are cases where they exert their effect only under certain conditions [31] [32]. In fact, under UV exposure and with a final concentration of $1000 \mu \mathrm{g} / \mathrm{ml}$, cell viability was significantly increased with KBY and CS. In addition, with $500 \mu \mathrm{g} / \mathrm{ml}$ as the final concentration, cell viability was significantly increased with $\mathrm{KBY}, \mathrm{KB}$, and $\mathrm{CS}$. As a result, no suppression of cell viability was observed under any condition, and the increased cell viability suggested that 
these compounds protect cells from UV damage. Together, these results suggest that the tyrosinase inhibitory effects of KBY, KB, and CS on melanin production were not attributable to their cytotoxicity. Moreover, KBY could be a safe whitening agent without influencing melanocyte growth if consumed after sunburn.

For tyrosinase activity under non-irradiated conditions, a significant increase was observed with both $\mathrm{KBY}$ and $\mathrm{KB}$; however, a significant decrease was observed with CS, regardless of the concentration. Under UV exposure, tyrosinase activity was significantly increased with $\mathrm{KBY}$ and $\mathrm{KB}$ at both concentrations, and the rate of increase in KBY was significantly lower than that of $\mathrm{KB}$ under any conditions. In brief, neither KBY nor KB inhibited tyrosinase activity, but CS had an inhibitory effect on this activity. From these results, we found that mixing $\mathrm{CS}$ with $\mathrm{KB}$ is important because the former plays a role to maintain the increase in tyrosinase activity to a minimum.

In contrast, when tyrosinase expression was considered under non-irradiated conditions, a significant decrease was only observed with KBY at both concentrations. Under UV exposure, tyrosinase expression significantly decreased with $\mathrm{KBY}$ and $\mathrm{KB}$ but was significantly increased with $\mathrm{CS}$ at both concentrations. These results suggest that KBY has a potent inhibitory effect on the expression of tyrosinase. Interestingly, for CS, the expression of tyrosinase increased under UV exposure. Although a further study is needed, with the inclusion of the tyrosinase activity results, we considered that the amount of CS mixed into KBY is a prescribed dose derived from years of experience, and this suppresses the tyrosinase activity promoting effect of KBY because of the compensatory tyrosinase activity inhibitory effect of CS. In addition, including this amount of CS does not hinder KBY's inhibitory effect on the expression of tyrosinase.

\section{Conclusion}

These results suggest that taking KBY after sunburn is effective against skin pigmentation, and the combination of $\mathrm{KB}$ and $\mathrm{CS}$ is useful for skin depigmentation.

\section{Conflicts of Interest}

The authors declare no conflicts of interest regarding the publication of this paper.

\section{References}

[1] Arai, Y., Iinuma, T., Takayama, M., Takayama, M., Abe, Y., Fukuda, R., et al. (2010) The Tokyo Oldest Old survey on Total Health (TOOTH): A Longitudinal Cohort Study of Multidimensional Components of Health and Longitudinal Cohort Study of Multidimensional Components of Health and Well-Being. BMC Geriatrics, 10, 35. https://doi.org/10.1186/1471-2318-10-35

[2] Uto, N.S., Amitani, H., Atobe, Y., Sameshima, Y., Sakaki, M., Rokot, N., et al. (2018) Herbal Medicine Ninjin'yoeito in the Treatment of Sarcopenia and Frailty. Frontiers in Nutrition, 5, 126. https://doi.org/10.3389/fnut.2018.00126 
[3] Diamanti-Kandarakis, E., Dattilo, M., Macut, D., Duntas, L., Gonos, E.S., Goulis, D.G., et al. (2017) Aging and Anti-Aging: A Combo-Endocrinology Overview. European Journal of Endocrinology, 176, 283-308. https://doi.org/10.1530/EJE-16-1061

[4] Cavinato, M., Waltenberger, B., Baraldo, G., Grade, C.V.C., Stuppner, H. and Jansen-Durr, P. (2017) Plant Extracts and Natural Compounds Used against UVB-Induced Photoaging. Biogerontology, 18, 499-516. https://doi.org/10.1007/s10522-017-9715-7

[5] Rexbye, H., Petersen, I., Johansens, M., Klitkou, L., Jeune, B. and Christensen, K. (2006) Influence of Environmental Factors on Facial Ageing. Age and Ageing, 35, 110-115. https://doi.org/10.1093/ageing/afj031

[6] Rapp, S.R., Feldman, S.R., Exum, M.L., Fleischer, A.B. and Reboussin, D.M. (1999) Psoriasis Causes as Much Disability as Other Major Medical Diseases. Journal of the American Academy of Dermatology, 41, 401-407. https://doi.org/10.1016/S0190-9622(99)70112-X

[7] Krasuska, M., Lavda, A.C., Thompson, A.R. and Millings, A. (2018) The Role of Adult Attachment Orientation and Coping in Psychological Adjustment to Living with Skin Conditions. The British Journal of Dermatology, 178, 1396-1403. https://doi.org/10.1111/bjd.16268

[8] Asakura, K., Nishiwaki, Y., Milojevic, A., Michikawa, T., Kikuchi, Y., Nakano, M., et al. (2009) Lifestyle Factors and Visible Skin Aging in a Population of Japanese Elders. Journal of Epidemiology, 19, 251-259. https://doi.org/10.2188/jea.JE20090031

[9] Davinelli, S., Bertoglio, J.C., Polimeni, A. and Scapagnini, G. (2018) Cytoprotective Polyphenols against Chronological Skin Aging and Cutaneous Photodamage. Current Pharmaceutical Design, 24, 99-105. https://doi.org/10.2174/1381612823666171109102426

[10] Castanedo-Cazares, J.P., Hernandez-Blanco, D., Garcia-Cortes, J.D., Medina-Aguilar, L. and Torres-Alvarez, B. (2018) Analysis of Cutaneous Pigmentation in a Sample. GacetaMedica de Mexico, 154, 68-73. https://doi.org/10.24875/GMM.M18000114

[11] Masaki, H. (2012) Hoshitsu Bihaku Koushiwa Kousannka Hyouka Jikken Manyuaru. Fragurance Journal Ltd., Tokyo.

[12] Suga, Y. (2006) Hifukaga Kangaeru Anti-Aging. Juntendo Igaku, 52, 429-436. (In Japanese) https://doi.org/10.14789/pjmj.52.429

[13] Numata, T., Kobayashi, Y., Ito, T., Harada, K., Tsuboi, R. and Okubo, Y. (2015) Two Cases of Allergic Contact Dermatitis Due to Skin-Whitening Cosmetics. Allergology International, 64, 194-195. https://doi.org/10.1016/j.alit.2014.10.007

[14] Tatebayashi, M., Oiso, N., Wada, T., Suzuki, K., Matsunaga, K. and Kawada, A. (2014) Possible Allergic Contact Dermatitis with Reticulate Postinflammatory Pigmentation Caused by Hydroquinone. The Journal of Dermatology, 41, 669-670. https://doi.org/10.1111/1346-8138.12526

[15] Kurokawa, I. (2015) Keishibukuryogankayokuinin to Seiyouyaku, Chemical Peeling, Ion Donyu no HeiyouniyotteEnsyogosikisochincyaku no Kaizen gaMitomeraretaJinjyoseizaso no Ichirei. KampoIgaku, 49, 197-198. (In Japanese)

[16] Kita, T. (2011) Basic Knowledge of the Kampo Medicine for Obstertrician and Gynecologist. Sanfujinka Chiryou, 103, 449-454. (In Japanese)

[17] Fujiwara, H., Ishikawa, S., Saito, H., Fukushima, M., Watanabe, K., Yoshida, Y., et al. (2012) Effect of Angelica Furcijuga on Melanin Production. Yakuri to Chiryo, 40, 587-593. (In Japanese) 
[18] Chang, Y.-H., Kim, C.T., Jung, M., Lim, Y.-H., Lee, S. and Kang, S. (2007) Inhibition of Melanogenesis by Selina-4(14),7(11)-dien-8-one Isolated from Atractylodis Rhizoma Alba. Biological \& Pharmaceutical Bulletin, 30, 719-723. https://doi.org/10.1248/bpb.30.719

[19] Ohguchi, K., Nakajima, C., Oyama, M., Iinuma, M., Itoh, T., Akao, Y., et al. (2010) Inhibitory Effects of Flavonoid Glycosides Isolated from the Peel of Japanese Persimmon (Diospyros Kaki "Fuyu") on Melanin Biosynthesis. Biological \& Pharmaceutical Bulletin, 33, 122-124. https://doi.org/10.1248/bpb.33.122

[20] Kim, K.S., Kim, J.A., Eom, S.Y., Lee, S.H., Min, K.R. and Kim, Y. (2006) Inhibitory Effect of Piperlonguminine on Melanin Production in Melanoma B16 Cell Line by Downregulation of Tyrosinase Expression. Pigment Cell Research, 19, 90-98. https://doi.org/10.1111/j.1600-0749.2005.00281.x

[21] Lee, W.J., Rhee, D.Y., Bang, S.H., Kim, S.Y., Won, C.H., Lee, M.W., et al. (2015) The Natural Yeast Extract Isolated by Ethanol Precipitation Inhibits Melanin Synthesis by Modulating Tyrosinase Activity and Downregulating Melanosome Transfer. Bioscience, Biotechnology, and Biochemistry, 79, 1504-1511. https://doi.org/10.1080/09168451.2015.1032880

[22] Kim, H., Choi, H.R., Kim, D.S. and Park, K.C. (2012) Topical Hypopigmenting Agents for Pigmentary Disorders and Their Mechanisms of Action. Annals of Dermatology, 24, 1-6. https://doi.org/10.5021/ad.2012.24.1.1

[23] Penney, K.B., Smith, C.J. and Allen, J.C. (1984) Depigmenting Action of Hydroquinone Depends on Disruption of Fundamental Cell Processes. The Journal of Investigative Dermatology, 82, 308-310.

https://doi.org/10.1111/1523-1747.ep12260588

[24] Otake, N. (2016) Ibo no KampoChiryo. Child Health, 19, 420-424. (In Japanese)

[25] Matsubara, Y., Matsumoto, T., Sekiguchi, K., Koseki, J., Kaneko, A., Yamaguchi, T., et al. (2017) Oral Administration of the Japanese Traditional Medicine Keishibukuryogan-ka-yokuinin Decreases Reactive Oxygen Metabolites in Rat Plasma: Identification of Chemical Constituents Contributing to Antioxidant Activity. Molecules, 22, 256. https://doi.org/10.3390/molecules22020256

[26] Yokoi, H., Mizukami, H., Nagatsu, A., Ohno T., Tanabe, H. and Inoue, M. (2009) Peroxisome Proliferator-Activated Receptor $\gamma$ Ligands Isolated from Adlay Seed (Coixlacryma jobi L. var. ma-yuen STAPF.). Biological \& Pharmaceutical Bulletin, 32, 735-740. https://doi.org/10.1248/bpb.32.735

[27] Hearing, V.J. (2005) Biogenesis of Pigment Granules: A Sensitive Way to Regulate Melanocyte Function. Journal of Dermatological Science, 37, 3-14.

https://doi.org/10.1016/j.jdermsci.2004.08.014

[28] Cha, S.-H., Ko, S.-C., Kim, D. and Jeon, Y.-J. (2011) Screening of Marine Algae for Potential Tyrosinase Inhibitor: Those Inhibitors Reduced Tyrosinase Activity and Melanin Synthesis in Zebrafish. The Journal of Dermatology, 38, 354-363. https://doi.org/10.1111/j.1346-8138.2010.00983.x

[29] Kim, Y.J. and Uyama, H. (2005) Tyrosinase Inhibitors from Natural and Synthetic Sources: Structure, Inhibition Mechanism and Perspective for the Future. Cellular and Molecular Life Sciences, 62, 1707-1723. https://doi.org/10.1007/s00018-005-5054-y

[30] Hearing, V.J. and Tsukamoto, K. (1991) Enzymatic Control of Pigmentation in Mammals. The FASEB Journal, 5, 2902-2909. https://doi.org/10.1096/fasebj.5.14.1752358

[31] Miyata, T. (2007) Pharmacological Basis of Traditional Medicines and Health Sup- 
plements as Curatives. Journal of Pharmacological Sciences, 103, 127-131. https://doi.org/10.1254/jphs.CPJ06016X

[32] Yokozawa, T., Sekiya, M., Rhyu, D.Y., Hattori, M. and Chung, H.Y. (2000) Radical-Scavenging Activity of Wen-Pi-Tang and Its Component Crude Drugs: With Special Reference to the Effects on Nitric Oxide, Superoxide and Peroxynitrite. Journal of Traditional Medicines, 17, 41-47. 